\title{
Acidity of New Exhaustively Substituted $p$-Nitrosophenols
}

\author{
D. G. Slashchinin, A. A. Kukushkin, and M. S. Tovbis \\ Siberian State Technological University, pr. Mira 82, Krasnoyarsk, 660049 Russia \\ e-mail:tovbis@bk.ru
}

Received June 6, 2011

DOI: $10.1134 / \mathrm{S} 1070428011090296$

A number of exhaustively substituted $p$-nitrosophenols I having ester groups in the ortho positions with respect to the hydroxy group were reported in [1].<smiles>[R]OC(=O)c1c(C)c([N+](=O)[O-])c(C)c(C(=O)O[R])c1O</smiles>

$$
\mathrm{R}=\mathrm{Me}(\mathbf{a}), \mathrm{Et}(\mathbf{b}), \operatorname{Pr}(\mathbf{c}), \mathrm{Bu}(\mathbf{d}), i \text {-Bu (e), }
$$$$
\mathrm{C}_{5} \mathrm{H}_{11} \text { (f), iso- } \mathrm{C}_{5} \mathrm{H}_{11} \text { (g). }
$$

We recently showed by the X-ray powder diffraction method that these compounds, unlike all known nitrosophenols, exist as dimers like azodioxides [2]. Hydrogenation of such polysubstituted nitrosophenols makes it possible to readily obtain the corresponding exhaustively substituted aminophenols [3] which are used in the synthesis of modern antiarrhythmic agents [4]. On the other hand, the acidity of compounds I was not studied. Only the acidity constant of diethyl 2-hydroxy-4,6-dimethyl-5-nitrosobenzene-1,3-dicarboxylate (Ib) was reported ( $\left.\mathrm{p} K_{\mathrm{a}} 5.35 \pm 0.04\right)$ [5].

We now report on the acidity of a series nitrosophenols Ia-Ig and its relation to the nature of alkyl group in the ester moieties. The acidity constants were determined by spectrophotometry [6] at $25.0 \pm 0.1^{\circ} \mathrm{C}$ using citrate buffer [7]. The $\mathrm{p} K_{\mathrm{a}}$ values are as follows:
Ia, 5.33 \pm 0.01 ; Ib, 5.35 \pm 0.04 ; Ic, 5.35 \pm 0.03 ; Id, 5.38 \pm 0.04 ; Ie, 5.58 \pm 0.03 ; If, $5.42 \pm 0.03$; Ig, $5.64 \pm 0.06$.

These data show that the acidity constant almost does not depend on the alkyl group in the ester fragments of exhaustively substituted $p$-nitrosophenols. We can only note some tendency of $\mathrm{p} K_{\mathrm{a}}$ to increase with increase in the size of the alkyl group.

\section{REFERENCES}

1. Belyaev, E.Yu., Tovbis, M.S., and El'tsov, A.V., Zh. Org. Khim., 1978, vol. 14, p. 2375.

2. Alemasov, Yu.A., Slaschinin, D.G., Tovbis, M.S., and Kirik, S.D., J. Mol. Struct., 2011, vol. 985, p. 184.

3. Slashchinin, D.G., Tovbis, M.S., Root, E.V., Zadov, V.E., and Sokolenko, V.A., Russ. J. Org. Chem., 2010, vol. 46, p. 517.

4. Eiden, F., Leister, H.P., and Mayer, D., Arzneim.-Forsch., 1983, vol. 33, p. 101.

5. Tovbis, E.M., Shkaberina, G.Sh., Doroshenko, I.Ya., Yakimov, S.P., and Tovbis, M.S., Izv. Vyssh. Uchebn. Zaved., Khim. Khim. Tekhnol., 2008, vol. 51, p. 111.

6. Albert, A. and Serjeant, E., Ionization Constants of Acids and Bases, London: Methuen, 1962. Translated under the title Konstanty ionizatsii kislot $i$ osnovanii, Moscow: Khimiya, 1964, p. 180.

7. Schwabe, K., Fortschritte der pH-Messtechnik, Berlin: Technik, 1953. Translated under the title Osnovy tekhniki izmereniya $\mathrm{pH}$, Moscow: Inostrannaya Literatura, 1962, p. 472. 